\title{
The effectiveness of family therapy in social case work method to develop family dialogue for the newly formed families
}

\section{By}

Dr. Ahmed Qenawi Hamid

Assistant Professor of social case work

The Higher Institute of Social Work, Qena 
مجلة كلية الخدمة الاجتماعية للدر اسات و البحوث الاجتماعية - جامعة الفيوم 


\section{Research Summary}

The Egyptian families suffer from many psychological, social, educational and economic problems that lead to many negative results, including: family instability and the absence of family dialogue and interaction. Therefore, this study seeks to test the extent of the return to family stability and balance through awareness of the importance of positive family dialogue using one of the therapeutic approaches in social case work, which is the family therapy, so the stability of family life is an essential factor for marital happiness, and marriage as the first step in forming a family may be reconciled if the positive family dialogue is achieved for him, especially in the modern family. .

The study aimed to test the effectiveness of family therapy in social case work to develop family dialogue in newly formed families. The main hypothesis of the study was that there are statistically significant differences between the pre and post measurement of the effectiveness of family therapy for developing family dialogue in newly formed families with the experimental group.

Among the most important results of the study is the validity of the main hypothesis of the study : There are statistically significant differences between pre and post measurement of the effectiveness of family therapy for developing family dialogue in newly formed families.

\section{key words:}


Family therapy - family dialogue - newly formed families.

\section{ملخص البحث}

تعيش الأسرة في مصر العديد من المشكلات النفسية والاجتماعية والتعليمية والاقتصادية تؤدى

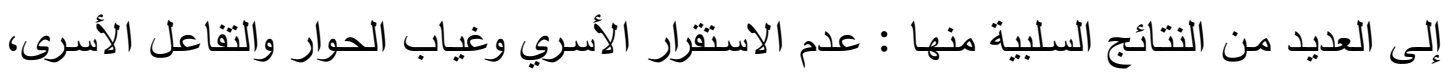

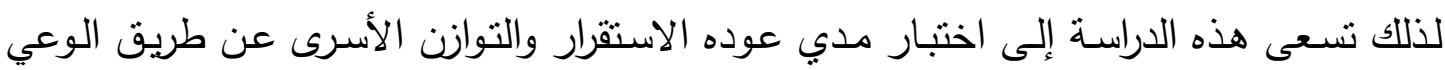

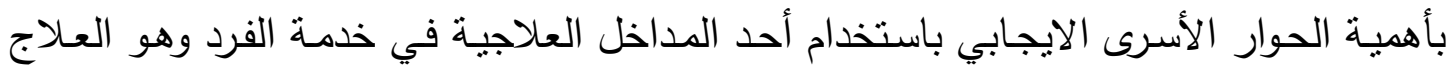
الأسرى، لذلك استقرار الحياة الأسرية عامل أساسي من عوامل السعادة الزوجية، والزواج الاجية باعتباره

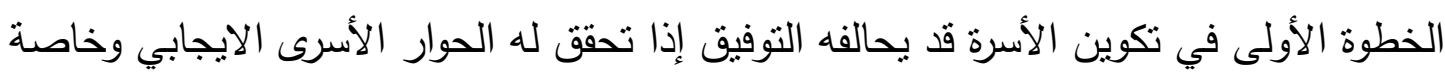

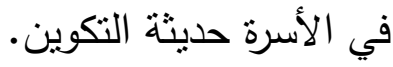

وهدفت الدراسة إلي اختبار فاعلية العلاج الأسرى في خدمة الفرد لتتمية الحوار الأسرى للى الأسر حديثة التكوين. وتمثل الفرض الرئيسي للدراسة في أنه توجد فروق ذاته ذات دلالة إحصائية

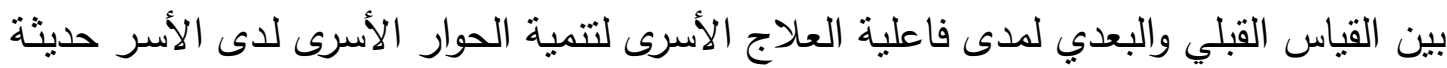
التكوين لاى المجموعة التجريبية. ومـن أهم نتائج الدراسـة صـحة الفرض الرئيس للاراسـة والذي مؤداه: نوجد فروق ذات دلاتلـة

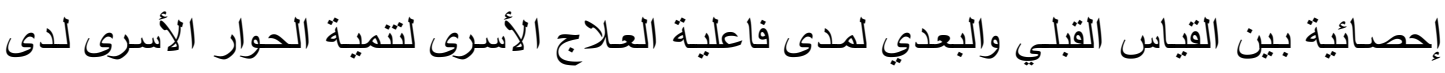
الأسر حديثة التكوين.

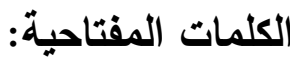
العلاج الأسري - الحوار الأسري - الأسر حديثة التكوين. 


\section{The study Problem :}

The importance of the current study lies in the high rate of divorce cases in Egypt to record levels, according to a study published by the Information and Support and Decision Center of the Egyptian Council of Ministers, where the percentage of divorce increased during the past fifty years from $7 \%$ to $40 \%$ and that one day by (240) divorce cases to reach the number divorced women in one year 2.5 million divorced women, and the study showed $70 \%$ of those who did not marry for more than five years, most of whom are young (Support and Decision Center, 2017).

The Egyptian families suffer from many psychological, social, educational and economic problems that lead to many negative consequences, including: family instability and the absence of dialogue and family interaction (Hassanein, 1999, p. 11; Abu AlNasr, 2019, p. 20). Therefore, this study seeks to test the extent of the return of family stability and balance by awareness of the importance of positive family dialogue using one of the therapeutic approaches in social case work, which is the family therapy, so the stability of family life is a key factor in marital happiness and increases in achieving that if the relations are characterized by friendliness and understanding between the couple.

Marriage as the first step in forming any family may be reconciled by success if the positive family dialogue between the two spouses is achieved, and when an obstacle appears that prevents them or one of them from satisfying the basic needs of the other party or obtaining legal rights, he or she feels deprivation, 
frustration, threats, insecurity and stability in his family relationship and is anxious Anger in his captivity and misunderstanding with the other party (Shukry, 2001).

Therefore, this study requires the development of family dialogue in order to continue social life in general and family life in particular, as it is considered as a way to express negative and positive feelings of family members in an acceptable manner and does not contain offense to others (Hassan, 2000, p. 25).

This is what Abdel-Fattah's study (2000) indicated about a suggested counseling program to enhance marital harmony through the techniques of family dialogue. This program was applied to a number of (20) married couples. Also, this study found that when there is a great opportunity for both husbands and wives to express themselves about what is inside them and gave them opportunities to hear each other and this makes them feel more satisfied and marital happiness than the absence of family dialogue between them.

The family dialogue requires many skills, including the skill in purposeful interaction between the spouses in a manner that ensures achieving a family balance and ensuring the future of the family and children, identifying conditional goals to achieve their aspirations and creating the appropriate general atmosphere in the guidance and proper education for the children, and the family context based on the dialogue must include the roles assigned to family patterns how to review it and determine the tasks assigned to each individual, and the susceptibility among family members to evaluate the roles and proper guidance through purposeful family dialogue (Barry, 2006).

To confirm this, study of Bacha (1999, p.25) indicates that one of the methods that achieve family compatibility is the partner places himself in the other party, that he or she learns his views and problems, and that he or she cooperates positively with family members and resort to his assistance to specialists or friends when family problems occur, and not to compare the partner with others and to be contented with what he owns and dialogue with the partner. 
The occurrence of family differences alters the form of family interaction between the spouses and the creation of conflicting trends between them that leads to a separation of the relationship between the spouses, which leads to a change in the positive view of the other and changes in the perception of each partner from the same position, which leads to frustration, anger and failure in communication and personal experiences that keep the couple away from Some of them, which leads to a lack of dialogue and communication (Moawad, 2004, p. 147).

The newly formed family is the family that includes a husband, wife, and children, or without children, and their marriage has passed for three years at most (El-Desouky, 2003). She is the husband and wife component, and their marriage has lasted between one and three years (Morna Orugh, 1993). This is what was indicated by the Mansour study (1999, p. 132) that was conducted on newly married women in Egypt, which shows that despite the degree of women's education, the desire to have children quickly in the beginning of marriage leads to many health and psychological problems for the wife resulting in the absence of family dialogue, especially in the rural village community whose reproduction is the main goal of marriage and its delay leading to separation.

The problems of the family in general and newly formed in particular are multiple and intertwined and are not due to one factor or reason always but rather to several interfering factors whose degrees of impact differ from the family to the other, but there are factors that interfere to some degree in the occurrence of family problems for newlyweds, including family conflict, disintegration, and the absence of dialogue, the result of the difference in thought and the economic and social pressures that emerged after the global transformations, and the gradual decline of family relations.

This was confirmed by Carin Levin study (1996), where it showed that there are a set of life styles that include the continued stability of family life between newlywed couples, including the absorption of stress, the use of free time, overcoming marital conflicts, conflict 
of roles and different culture resulting from the absence of dialogue Marriage is based on respect and understanding based on bringing happiness and agreement to face all life pressures.

This is the study Alexandra Hambrights (2001) confirmed that intellectual cultural differences play a large role in the problems of newlyweds leading to frequent family tendencies and weak family dialogue, in addition to the difference in expecting roles in overcoming marital conflicts and facing conflict of roles and cultural difference resulting from family dialogue. The relationship should be between respect and understanding in order to achieve happiness and that the spouses work to face the stresses of life.

Therefore, a study Walter Schumn \& et. al. (2000) illustrates the development of a mentoring program for newly formed families in order to alleviate family stress and problems of lack of marital dialogue and provide advice using family therapy.

Family therapy is defined as that intervention by a professional social worker and family therapy specialists with family members who are the focus of attention of the therapist as individual units, and as a model for an approach that focuses on the overall layout of individuals, internal personal patterns, and communication.

Also, family therapy aims to take care of the roles, responsibilities and reciprocal obligations between family members, and encourages consensual behaviors between family members, and the family therapist focuses on verbal and non-verbal communication today using the tactics and methods of family therapy (Robert Barker, 2003, p. 170).

A family therapy for an individual who suffers from a problem is seen as a symptom of a family suffering from some disorders and problems. Therefore, treatment of this symptom requires the treatment of the whole family. (Froma wolsh, 1982, p 113). To confirm this, what the study of Jabal (1985, p. 24) indicated, that social case work method using family therapy with marital conflict situations has a positive effect on increasing family employment, in addition to that family therapy is an inexpensive input in time and effort, and is suitable for practice in guidance offices And family counseling. 
Also what was indicated by the study of Abdel-Al (1999), where it aimed to try to measure the effect of family therapy methods in improving the marital compatibility rate between the spouses in the family, and the study concluded that there are individual differences of statistical significance between the tribal and the dimensional measurement on the marital compatibility scale in favor of the dimensional measurement, which indicates to the effectiveness of family therapy in increasing the rate of marital harmony between spouses in the family.

The current study aimed at practicing family therapy as one of the therapeutic approaches in social case work method to develop the family dialogue for newly-formed families in the absence of this positive dialogue that helps to continue the family life and its stability through developing family acceptance skills and communication skills and achieving interaction between family members and the practice of technical dialogue between family members.

\section{Aims of the study:}

This study aimed to test the effectiveness of family therapy in social case work method to develop family dialogue in newly formed families, by achieving:

1- Testing the effectiveness of family therapy in achieving family acceptance among family members.

2- Testing the effectiveness of family therapy in developing the skill of communication between family members

3- Testing the effectiveness of family therapy in achieving interaction between family members

4- Testing the effectiveness of family therapy in practicing the techniques of dialogue between family members

\section{The Study Concepts:}

\section{The concept of family therapy :}

- Family therapy is one of the therapeutic approaches in the social case work method.

- Family therapy focuses on opening communication channels between family members. 
- Family therapy is concerned with achieving balance within the family.

- Family therapy focuses on building positive values and attitudes within the family using therapeutic techniques.

\section{The concept of family dialogue:}

- Dialogue in general is a direct, two-way, two-way communication process in which both sides of the modern dialogue exchange and listen on a common topic that concerns both parties (Abo El-Nasr, 2015, p. 5)

- The family dialogue is the positive communication between family members and the fruitful interaction that achieves cooperation between family members, and based on respect for each family member's conversation, which is the continuous exchange of ideas and visions between family members to confront any problem that affects family stability.

The concept of a newly formed family:

- It is a family that consists of a husband, wife, children, or without children.

- It is the family who have not been married for five years.

- This family is made up mostly of young people.

- This family describes a lack of marital experience between the spouses.

The methodological framework of the study:

The Study type:

The present study is a quasi-experimental study. In general, this type of studies is concerned with the process of observing and measuring the phenomenon after modifying it partially or completely or after introducing the experimental variable on it to know whether a change occurred or not and what is the degree and type of this change compared to the situation before applying the experiment.

The Study Method :

The current study curriculum is the experimental approach.

The Study Hypotheses:

The current study tries to test the following hypotheses:

The main hypothesis of the study: 
There may be statistically significant differences between the pre and post measurement for the effectiveness of family therapy for developing family dialogue in newly formed families with the experimental group.

\section{The Sub-hypotheses of the study :}

1- There is a statistically significant relationship between the effectiveness of family therapy and achieving family acceptance in newly formed families.

2- There is a statistically significant relationship between the effectiveness of family therapy and the development of communication skills in newly formed families.

3- There is a statistically significant relationship between the effectiveness of family therapy and the achievement of family interaction in newly formed families.

4- There is a statistically significant relationship between the effectiveness of family therapy and the development of the skill of dialogue art in newly formed families.

\section{Fields of the study :}

- The Human field :The study was applied to a non-random sample of (10) cases from the attendants at the Family and Marital Counseling Office in Qena Governorate, and the number of the visitors to the office was (50) husband and wife during the study period and they have family problems.

The conditions or criteria for selecting the study sample were as follows:

1- that the marriage be established.

2- The marriage period should be more than five years.

3- To be a frequent visitor to the marital and family counseling office.

4- That the problems result from the absence of the family dialogue.

5- The family's consent to implement the professional intervention program through oral or written contracting.

- The Spatial field :The family counseling office in Qena Governorate, where the office is within the scope of the researcher's work and residence. 
- The Time field :The study was conducted in its theoretical and field form from 1/2 / 2018 until 27/9 / 2018.

The Study tool:The researcher collected data through the family dialogue scale (prepared by the researcher). The researcher has taken the following steps in preparing the scale:

1- Reviewing the theoretical writings related to family disputes.

2- Reviewing previous Arab and foreign studies related to family dialogue and its components of family acceptance, positive communication, family interaction and dialogue techniques.

3- Reviewing the relevant scales for the subject of the study, including:

- The Family Adjustment Scale, by Munira Abdullah AlShamsan (2004).

- Marital satisfaction by Scote walter w. H adson

- The Family Adjustment Scale, by David Alson and Joyce Yurtter,

- The family adaptability scale, by lohesion D. Olson. v. Pantnes

- The Marital Dialogue Scale prepared by Dalia Naim Abdel Wahab (2016)

- The Marital adaptation scale , by Abdullah Gad Mahmoud (2006).

After reviewing the theoretical writings, previous research studies, and previous scales reached by the researcher on this topic with a view to formulating definitions of the basic terms included in this scale, the researcher determined the main dimensions of the scale through which the development of the family dialogue is measured and these are the following dimensions: Family Acceptance , Communication skills, Family interaction, Techniques of dialogue Family acceptance:The extent of acceptance and respect based on love, compassion and reassurance among family members without this acceptance being exaggerated in its manifestation or distance from it, and the sentences of this dimension (15), such as:

- Accept my family members as they are 
- My relationship with the family is characterized by love and respect.

- Tolerance is right when a problem arises towards the family

- Always make my family happy

- Reduce sorrow and pain on my family

- Take into account the feelings of family members unnecessary

Communication skill: It is the process of transferring the message from the sender to the receiver in a clear manner through a set of symbols, concepts and roles between the parties to the communication process that are generated during the interaction with the aim of influencing their ideas and convincing them of the content of the message, and the sentences of this dimension (15), such as :

- Smiling prevails in the face of family members when discussing family matters.

- The hadiths in the family are excellent, expressing candor and clarity

- There is an understanding in the ideas between the spouses by looking at the sample.

- There is no good communication between the spouses.

Family interaction: It means that there is a degree of social relations within the family that results in a series of interactions in life matters to confront problems in a positive way. The number of sentences for this dimension (16) such as:

- Cooperating with family members when family disputes occur.

- Participating with family members in accomplishing household chores.

- Sharing my family's leisure times.

- Going out with my family on public occasions.

- Living in isolation within the family prevents the problem.

Techniques of dialogue: It is meant to follow the party and the methods that make the dialogue successful in the family, and that brings the views between the family members and makes each party understand the opinions of the other party when discussing 
family matters. The expressions of this dimension were about (17) sentences, such as:

- Keeping silent when a dispute occurs between family members.

- Avoiding including other parties when a problem occurs in the family.

- Listening well when family members speak.

- Resorting to the threat of punishment when a problem occurs in the family

- Facing the family problem with calm way.

- Speaking in a low voice when discussing family life matters.

- Paying attention to the decision in order to increase cultural awareness of matters of family life.

Validity and reliability of the scale:

First: Validity of the scale : The researcher presents the scale in its first image to (6) arbitrators or reviewers from professors of social work and psychology to ensure the validity of the scale and verify its correction and validity of its sentences as well as the association of the sentences with each other and its connection to the scale as a whole has been deleted some of the sentences and add some other sentences or modify some of the sentences by the arbitrators or reviewers by no less than (85\%) between agreement between them on these sentences, and the researcher excluded the sentences that did not achieve this percentage and their number was (24) sentences, thus the scale became in its final form and the number of its sentences was (40) words.

Scale weights: The scale consists of (40) sentences, of which (27) are positive sentences and (13) are negative sentences. The researcher gave scores for positive ones $(1,2,3)$ and vice versa for negative ones $(3,2,1)$, respectively, as shown in the following table:

\begin{tabular}{|r|r|r|}
\hline \multicolumn{2}{|c|}{ Degree } & Responses \\
\hline Negative & Positive & \\
\hline 1 & $r$ & Yes \\
\hline$r$ & $r$ & To some extent \\
\hline
\end{tabular}


Second: Reliability of the scale ( Test-Retest ) The researcher calculated the reliability of the scale using the re-test method, as the scale was applied to a number of (10) families at the Office of Family Guidance and Consulting and the conditions of the sample apply to them with a time interval (15) days and they are not members of the sample that have therapeutic intervention, and the researcher calculated a factor Pearson correlation for each dimension of the scale. The correlation coefficient on the scale as a whole $(0,85)$, meaning that the scale is highly reliable and the following table shows the total reliability of the dimensions of the scale:

\begin{tabular}{|c|c|l|c|}
\hline Level of significance & Degree & Dimension & No. \\
\hline function of $\cdot, \cdot 1$ & $\cdot, \wedge \vee$ & Family Acceptance & 1 \\
\hline function of 0.01 & $\cdot, \wedge \circ$ & $\begin{array}{l}\text { Communication } \\
\text { skills }\end{array}$ & $r$ \\
\hline function of 0.01 & $\cdot, \wedge \wedge$ & Family interaction & $r$ \\
\hline function of $\cdot, \cdot 1$ & $\cdot, \wedge \varepsilon$ & $\begin{array}{c}\text { Techniques of } \\
\text { dialogue }\end{array}$ & $\varepsilon$ \\
\hline
\end{tabular}

It is clear from the table that the application of the Pearson coefficient of the reliability factor of the scale as a whole $(85 \%)$, which is a function at the level of $(0.01)$, and this indicates the reliability of the scale between the first application and the second application, and thus the scale becomes applicable in its final form.

The Statistical treatments used: Percentages, Spearman's coefficient, and T-test and the professional intervention program. The researcher in his work with cases relied on a professional intervention program and the goals of this program were the same as the aims of the study:

The overall or main aim : Measuring the effectiveness of family therapy in developing family dialogue in newly formed families through the following sub-goals.

\section{The sub-aims :}

1- Achieving family acceptance in newly formed families.

2- Developing communication skills of newly formed families. 
3- Achieving family interaction among newly formed families.

4- Developing the art of dialogue within newly formed families.

The professional intervention program had the stages:

\section{The first stage : The starting stage}

It is considered one of the most important stages in the professional intervention, as it builds upon the following steps and ensures full familiarity with family therapy in the social case work method the following steps:

1- Reviewing the theoretical heritage related to family therapy and previous studies

2- Completing the contracting process with clients.

3- Obtaining the approval of the authority in which the study will be applied.

4- Preparing the study tools.

5- Knowing the starting point for the problem by agreeing on the content of each problem, and this is done in light of choose the study sample.

6- Evaluating the current situation of newly formed families.

7- Appropriating start with spouses, applying the principle of acceptance to them, and achieving the frequency and anxiety associated with them during professional interviews.

8- Studying the characteristics of clients to know the differences between them.

9- Learning about the nature of the positive family dialogue through getting to know.

\section{The second stage: The implementing stage}

In this stage, the researcher in cooperation with families, identified the reasons for the absence of family dialogue and its impact on family stability and cohesion. He focused at this stage on the form and nature of family acceptance between spouses, as well as the nature of communication and interactions that took place between family members, as well as those around the family who have a relationship with the situations that cause family conflicts.

He stand on the opinion of each individual in the other, and get acquainted with the role of each individual within the family. Also the researcher helped the family to open communication channels 
that helped to conduct a positive dialogue. He helped the family to establish relationships of mutual respect based on acceptance. Also ,the researcher helped the family on effective cooperation in the completion of the family business, as well as confidence and calm when dialogue and skill in understanding the responsibilities, duties and re-distribution of roles within the family so as to achieve the family balance as well as modify the values, customs and harmful traditions that threaten the stability and cohesion of families using methods and techniques of family therapy.

\section{Among these therapeutic technics :}

1- Communication technics : Opening new channels of communication between the spouses by opening a family dialogue in everything related to the family, expressing their feelings towards each other, strengthening the channels of communication between family members that improve the relations between them that generate interest and respect, preserving the feelings of each party, as well as clarifying the couple's nature of the new stage in their life, which is the formation of a newly formed family. Focusing on family based on cooperation, and introducing them to all the institutions in society that support family life through experience, advice and material support so that the family is familiar with all the services that are provided to newly formed families.

2- Styles of Restoring a Family Balance: The researcher here tried to help family members to stability and flexibility to meet the new requirements for developing family dialogue, and to maintain stability and distance from conflicts and helped to achieve effective family dialogue in facing the changes required to achieve family stability because the interruption of family dialogue leads to marital breakdown, for that dialogue It leads to rest, psychological stability and emotional equilibrium, and thus the therapist achieves a family balance.

3- Styles of family interaction: Where the researcher helped the family members to cooperate positively between family members and help them deal with conflicts resulting from interaction through guiding purposeful dialogue within the 
family pattern by not raising voices when discussing, and not using profanity, insulting and slandering, and underestimating the other, which affects the nature of relationships between family members, strengthening positive values such as ensuring the future of the family and children, setting legitimate goals for achieving their ambitions, and creating an atmosphere of interaction and cooperation between family members.

4- Modifying negative values and customs that conflict with the values of family and society: Like some behaviors when husbands are accustomed to going out to the street for long periods of the day, as well as not accepting the wife going out to work from the husband, as well as spending long periods on the Internet and watching negative phenomena that are difficult to achieve in family life and her uncle produces family disputes that lead to separation.

5- Professional relationship: The professional relationship aimed to reduce tension between family members and create a psychological climate by strengthening the relationship between the researcher and the family members to identify internal feelings and ideas about the nature of the family relationship between the spouses as well as showing confidence, reassurance and respect on the part of the researcher helps to strengthen the professional relationship to achieve the assistance or helping process.

Direct impact technics : These include increasing positive feelings and thoughts of family members during the interaction between them, and this is done within the framework of advice, suggestion, affirmation, support of the higher self, and confirming successful coping experiences between spouses within the family pattern.

1-Empathy Ventilation :Empathy ventilation was used to help the husbands to express their suffering from the negative family conditions resulting from the absence of a successful family dialogue, with the aim of emotional venting on them and alleviating these family problems, through encouraging and strengthening to 
continue to produce these feelings and employ them in favor of a positive family dialogue.

2-Encouragement: In order to encourage the spouses to identify their misconceptions about the nature of family life and their excitement to amend these ideas and to understand their rights and the duties of each individual within the family and support positive behaviors issued by the spouses in a manner that supports the stability and continuity of family life between them.

\section{The third stage: Evaluation and termination stage}

This stage had done by reviewing what has been accomplished during the application of the program and confirmation of the use of family therapy has reached the achievement of the required goals which is the development of family dialogue in newly formed families and this is achieved through measuring the return of professional intervention after conducting the dimensional measurement of the experimental group and identifying the degree of improvement in the family dialogue when families, extract the meaning of differences, and prepare the client (family) to end the professional relationship.

\section{Program tools:}

The researcher relied on the program implementation on:

1- Individual interviews between the researcher and family members.

2- The joint interviews between the researcher, the spouses or relatives.

3- Family sessions that take place in the family in the presence of the researcher.

\section{Data tabulation, analysis and interpretation :}

\section{Table No. (1)}

Statistical significance of the differences between the average scores of the study cases on the communication skill index for the newly married in the pre and post measurements

\begin{tabular}{|c|c|c|c|c|c|c|c|}
\hline \multirow{2}{*}{$\begin{array}{l}\text { statistical } \\
\text { significance } \\
\text { at } 0.001\end{array}$} & \multirow{2}{*}{$\begin{array}{l}\text { tabul } \\
\text { ated } \\
\text { valu } \\
\text { e of }\end{array}$} & \multirow{2}{*}{$\begin{array}{l}\text { deg } \\
\text { ree } \\
\text { s of } \\
\text { free }\end{array}$} & \multirow{2}{*}{$\begin{array}{r}\text { calc } \\
\text { ulat } \\
\text { ed } \\
\text { valu }\end{array}$} & \multicolumn{2}{|c|}{$\begin{array}{l}\text { Post- } \\
\text { measurement }\end{array}$} & \multicolumn{2}{|c|}{$\begin{array}{c}\text { Pre- } \\
\text { measurement }\end{array}$} \\
\hline & & & & $\begin{array}{l}\text { standard } \\
\text { deviation }\end{array}$ & $\begin{array}{l}\mathrm{Av} \\
\mathrm{ac}\end{array}$ & $\begin{array}{l}\text { stand } \\
\text { ard }\end{array}$ & $\begin{array}{l}\text { Aver } \\
\text { age }\end{array}$ \\
\hline
\end{tabular}




\begin{tabular}{|c|c|c|r|l|l|l|l|}
\hline & $(T)$ & $\begin{array}{c}\text { do } \\
m\end{array}$ & $\begin{array}{r}\text { e of } \\
(T)\end{array}$ & & $\begin{array}{r}\text { scor } \\
\text { e is }\end{array}$ & $\begin{array}{l}\text { deviat } \\
\text { ion }\end{array}$ & score \\
\hline $\begin{array}{c}\text { statistical } \\
\text { significance }\end{array}$ & $r, I \leqslant$ & $I \leqslant$ & $\varepsilon, l r$ & $r, r$ & $r r, r$ & $r, r \varepsilon$ & $r, r, r$ \\
\hline
\end{tabular}

It is clear from Table No. (1) that the calculated value of (T) in the pre and post measurement of communication skill between newlyweds from the experimental group is greater than the tabulated value of $(T)$ at the level of statistical significance $(0,01)$ with a degree of confidence $(0,99)$ and that shows There are statistically significant differences between the pre and post measurements by practicing family therapy in developing the communication skill of the newly married.

Table No. (2)

The tabulated value of $(T)$ and the calculated value of $(T)$ and its statistical significance of the family acceptance index with the experimental group with newly married families on the family dialogue scale

\begin{tabular}{|c|c|c|c|c|c|c|c|}
\hline \multirow[b]{2}{*}{$\begin{array}{l}\text { statistical } \\
\text { significance } \\
\text { at } 0.001\end{array}$} & \multirow[b]{2}{*}{$\begin{array}{c}\text { tabul } \\
\text { ated } \\
\text { valu } \\
\text { e of } \\
\text { (T) }\end{array}$} & \multirow{2}{*}{$\begin{array}{l}\text { deg } \\
\text { ree } \\
\text { s of } \\
\text { free } \\
\text { do } \\
m\end{array}$} & \multirow{2}{*}{$\begin{array}{r}\text { calc } \\
\text { ulat } \\
\text { ed } \\
\text { valu } \\
\text { e of } \\
\text { (T) }\end{array}$} & \multicolumn{2}{|c|}{$\begin{array}{c}\text { Post- } \\
\text { measurement }\end{array}$} & \multicolumn{2}{|c|}{$\begin{array}{c}\text { Pre- } \\
\text { measurement }\end{array}$} \\
\hline & & & & $\begin{array}{l}\text { standard } \\
\text { deviation }\end{array}$ & $\begin{array}{l}\text { Aver } \\
\text { age } \\
\text { scor } \\
e \text { is }\end{array}$ & $\begin{array}{l}\text { stand } \\
\text { ard } \\
\text { deviat } \\
\text { ion }\end{array}$ & $\begin{array}{r}\text { Aver } \\
\text { age } \\
\text { score }\end{array}$ \\
\hline $\begin{array}{c}\text { statistical } \\
\text { significance }\end{array}$ & $r, \varepsilon$ & $1 \leqslant$ & $\varepsilon, \wedge \wedge$ & $r, T r$ & $\leqslant 0, r$ & $r, Y T$ & $\varepsilon r, \varepsilon$ \\
\hline
\end{tabular}

It is clear from Table No. (2) that the calculated value of (T) is greater than the value of the $(T)$ table in the pre- and postmeasurement of the family acceptance index among newly married families, at the level of statistical significance $(0,01)$ and with a degree of confidence $(0,99)$, and that shows the effectiveness of family therapy in achieving family acceptance is one of the indicators of family dialogue among newly married families.

Table No. (3) 
The tabulated value of $(T)$ and the calculated value of $(T)$ and its statistical significance for the family interaction index for the experimental group on the family dialogue scale

\begin{tabular}{|c|c|c|c|c|c|c|c|}
\hline \multirow[b]{2}{*}{$\begin{array}{l}\text { statistical } \\
\text { significance } \\
\text { at } 0.001\end{array}$} & \multirow[b]{2}{*}{$\begin{array}{c}\text { tabul } \\
\text { ated } \\
\text { valu } \\
\text { e of } \\
(\mathrm{T})\end{array}$} & \multirow{2}{*}{$\begin{array}{c}\text { deg } \\
\text { ree } \\
\text { s of } \\
\text { free } \\
\text { do } \\
m\end{array}$} & \multirow{2}{*}{$\begin{array}{r}\text { calc } \\
\text { ulat } \\
\text { ed } \\
\text { valu } \\
\text { e of } \\
\text { (T) }\end{array}$} & \multicolumn{2}{|c|}{$\begin{array}{c}\text { Post- } \\
\text { measurement }\end{array}$} & \multicolumn{2}{|c|}{$\begin{array}{c}\text { Pre- } \\
\text { measurement }\end{array}$} \\
\hline & & & & $\begin{array}{l}\text { standard } \\
\text { deviation }\end{array}$ & $\begin{array}{l}\text { Aver } \\
\text { age } \\
\text { scor } \\
\text { e is }\end{array}$ & $\begin{array}{l}\text { stand } \\
\text { ard } \\
\text { deviat } \\
\text { ion }\end{array}$ & $\begin{array}{r}\text { Aver } \\
\text { age } \\
\text { score }\end{array}$ \\
\hline $\begin{array}{c}\text { statistical } \\
\text { significance }\end{array}$ & $r, 1 \varepsilon$ & $1 \leqslant$ & $r, 0 \leqslant$ & $r, 11$ & $r q, r$ & $r, Y T$ & $r T, T$ \\
\hline
\end{tabular}

It is clear from Table No. (3) that the calculated value of (T) is greater than the value of the $(T)$ tabular with degree of freedom (14) and statistically significant at the level of significance $(0,01)$ and with a degree of confidence $(0,99)$, which shows the presence of statistically significant differences between The pre and post measurements of the experimental group members in favor of family therapy techniques in achieving family interaction is one of the indicators of family dialogue among newly married families.

\section{Table No. (4)}

The calculated value of $(T)$, the calculated value of $(T)$ and its statistical significance for the family dialogue techniques index for the experimental group on the family dialogue scale

\begin{tabular}{|c|c|c|c|c|c|c|c|}
\hline \multirow[b]{2}{*}{$\begin{array}{l}\text { statistical } \\
\text { significance } \\
\text { at } 0.001\end{array}$} & \multirow[b]{2}{*}{$\begin{array}{c}\text { tabul } \\
\text { ated } \\
\text { valu } \\
\text { e of } \\
(\mathrm{T})\end{array}$} & \multirow{2}{*}{$\begin{array}{l}\text { deg } \\
\text { ree } \\
s \text { of } \\
\text { free } \\
\text { do } \\
m\end{array}$} & \multirow{2}{*}{$\begin{array}{r}\text { calc } \\
\text { ulat } \\
\text { ed } \\
\text { valu } \\
\text { e of } \\
(\mathrm{T})\end{array}$} & \multicolumn{2}{|c|}{$\begin{array}{c}\text { Post- } \\
\text { measurement }\end{array}$} & \multicolumn{2}{|c|}{$\begin{array}{c}\text { Pre- } \\
\text { measurement }\end{array}$} \\
\hline & & & & $\begin{array}{l}\text { standard } \\
\text { deviation }\end{array}$ & $\begin{array}{l}\text { Aver } \\
\text { age } \\
\text { scor } \\
e \text { is }\end{array}$ & $\begin{array}{l}\text { stand } \\
\text { ard } \\
\text { deviat } \\
\text { ion }\end{array}$ & $\begin{array}{r}\text { Aver } \\
\text { age } \\
\text { score }\end{array}$ \\
\hline $\begin{array}{c}\text { statistical } \\
\text { significance }\end{array}$ & $r, 1 \leq$ & $1 \leqslant$ & 0,1 & 1,174 & $r \uparrow, \Lambda$ & 1,1 & $r r, \Lambda$ \\
\hline
\end{tabular}

It is clear from Table No. (4) that the calculated value of $(T)$ is greater than the value of $(\mathrm{T})$ tabular with a degree of freedom (14) and statistically significant at the level of significance $(0,01)$ with a 
degree of confidence $(0,99)$, which shows the presence of statistically significant differences between the pre and post measurements of the experimental group members in favor of family therapy techniques in social case work to achieve family dialogue techniques in newly formed families.

\section{Main study results:}

1-The study proved the validity of the first hypothesis that performed: there is a significant relationship between the effectiveness of family therapy and achieving family acceptance in newly formed families, due to the effectiveness of the professional intervention program using family therapy in social case work through the use of family therapy techniques to achieve acceptance and existing respect on love and affection among married couples.

One of these techniques that was used in achieving family acceptance is the presentation of negative values and habits that conflict with stable family values and emotional emptying method to reduce tension and anxiety within the family and restore the family balance that results in the stability of marriage generates positive family dialogue.

This is in line with the Wissam Al-Hamwi study (2006) that found the characteristics of a successful marriage represented in understanding and acceptance between the spouses, mutual trust between family members, mutual love between spouses, flexibility in the treatment of the other party, and appreciation for the efforts of the other party, the independence of the spouses from parents in decision-taking and the educational level converging between the spouses, an appropriate period of acquaintance before marriage, and the availability of an appropriate economic level, the affiliation of the spouses to a similar social environment, and the rapprochement between the spouses in age, body language, and form.

2-The study found the validity of the second hypothesis that led to it: there is a significant relationship between the effectiveness of family therapy and the development of communication skill among newly formed families, due to the effectiveness of the professional 
intervention program using family therapy techniques where new communication channels between the spouses were opened and then a family dialogue was opened positive and expressing their feelings freely, as well as strengthening channels of communication between family members that improve their relations and strengthen mutual respect, as well as introducing them to all institutions in society that provide experiences, advice and material support so that the family is stable, as well as the clarity of the message and the language of the mutual communication between family members

This is consistent with the study of Khaled Mohamed El-Sayed Hassanein (2010), which confirmed the effectiveness of a knowledge program from the group work method perspective in the ability of social workers working in the family field to provide newly formed some family life skills such as communication skill by opening new communication channels and strengthening communication channels other than to be active in a positive way, as well as providing them with the skill to solve marital problems and the skill in creating the appropriate environment for the continuation of stable family life.

3-The study concluded the validity of the third hypothesis that led to it: There is a significant relationship between the effectiveness of family therapy and the achievement of family in newly formed families, due to the effectiveness of the professional intervention program using family therapy methods and techniques, including helping families to positive cooperation and helping them to deal with family conflicts during the discussion and purposeful dialogue that is far away from loud voices during the discussion and away from profanity and slander, to underestimate the other and to encourage the identification of misconceptions about their family life and to amend these ideas and understand their rights, as well as support positive behaviors in the distributing family responsibilities between the spouses in a way that achieves family stability that leads to successful dialogue, by using direct impact methods such as maturity, suggestion, assertiveness, support of 
the higher self, and stabilizing experiences of successful interaction between spouses within the family setting.

This is consistent with the Herrey joanning study (2007) which seeks to identify the near-term and long-term impact of intercourse between spouses through a program that has been applied and generalized through measures of marital adaptation, quality of behavioral communication and degrees of family interaction between spouses. The study resulted in the need of the couple for further training on marital life skills, especially the skill of family interaction.

4-The study concluded the validity of the fourth hypothesis, which leads to it: There is a significant relationship between the effectiveness of family therapy and the development of the skill of dialogue art among newly formed families, due to the effectiveness of the professional intervention program using family therapy methods that aim to follow the purposeful dialogue that prevails in mutual respect, as well the method of adjusting values and attitudes through modifying false ideas about how to conduct dialogue between spouses, especially from husbands, as well as good listening to different views within the family and adopting and supporting positive opinions, and opening positive channels of communication that support dialogue within the family and affirmation the difference in opinions is consistent with the Muhammad bin Salem bin Muhammad AI-Qarni study (2008) that found the effectiveness of designing a behavioral cognitive therapeutic program to reduce marital fatigue by developing the skills of a culture of dialogue between spouses and achieving positive communication and dialogue.

It also agreed with the Hanan Hassan Ahmed study (2012) that reached the effectiveness of the knowledge entrance in raising the awareness of female university students who are about to marry a family dialogue. The most important results of that were that family dialogue reduces rates of family problems such as divorce, marital alienation, and child delinquency. 


\section{مراجع البحث}

\section{أولا : المراجع العربية}

1. أميرة منصور يوسف(1999) ـ المدخل الاجتماعى للسكان والأسرة، دار المعرفة الجامعية ، الاسكندرية.

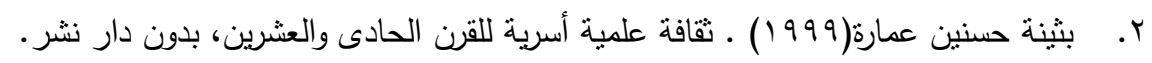

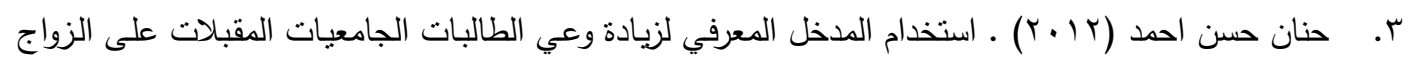

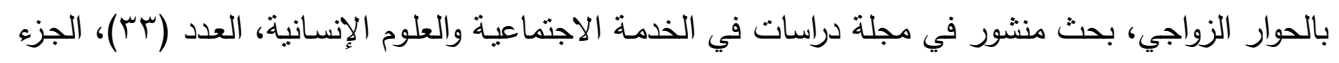
(^)، كلية الخدمة الاجتماعية، جامعة حلوان ، القاهرة.

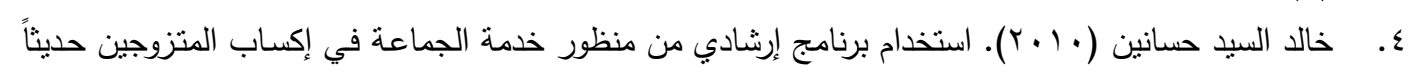
بعض المهارات الحياة الزوجية، بحث منشور في المؤتمر العلمي الثالث والعشرون، كلية الخدمة الاجتماعية، جامعة حلوان، القاهرة. ه. زينب معوض الباهى(؟ . . r). منطلبات تعلم الحياة الأسرية للأسر حديثه التكوين المؤتمر العلمي السابع عشر كلية الخدمة الاجتماعية جامعة حلوان.

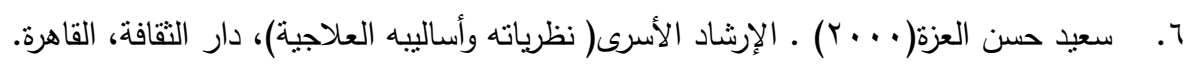

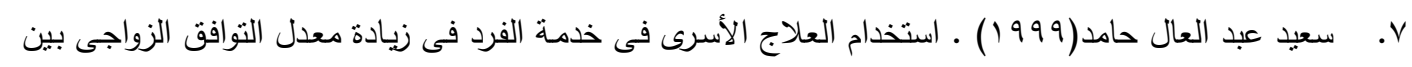

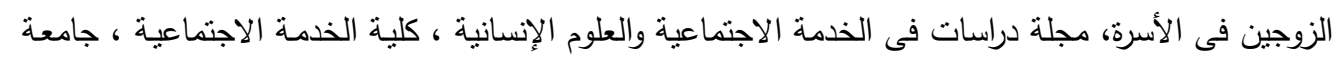
حلوان ، القاهرة.

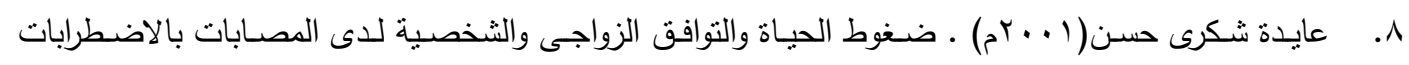

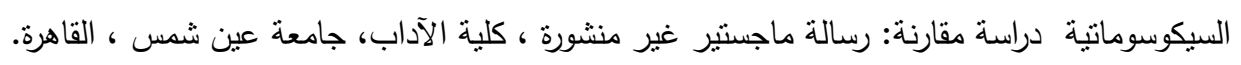

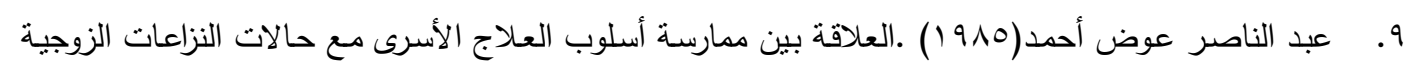

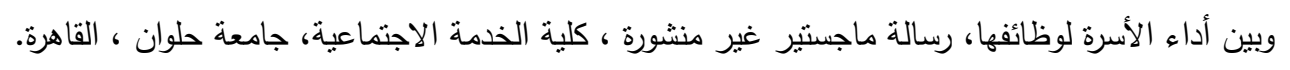

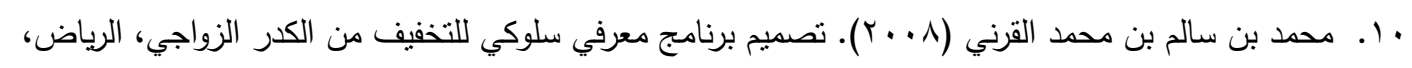

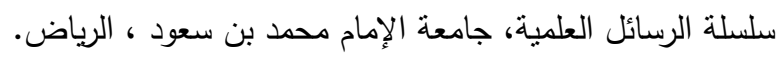

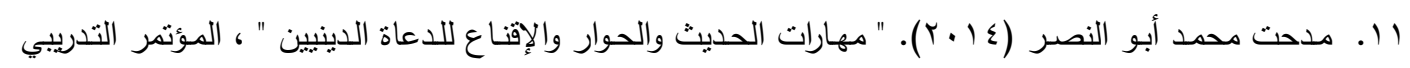

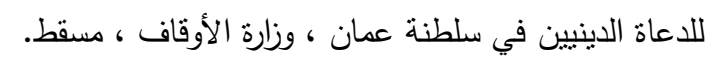

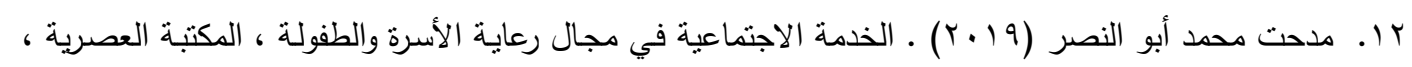
المنصورة. 


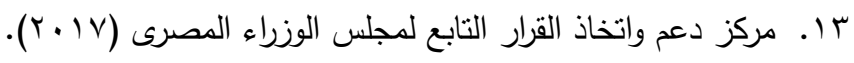

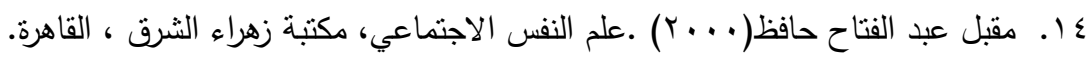

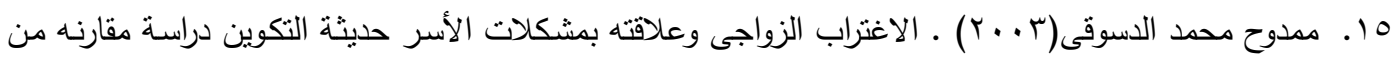

$$
\begin{aligned}
& \text { منظور خدمة الفرد ، بحث منشور ، مجلة كلية الخدمة الاجتماعية جامعة حلوان ، القاهرة. }
\end{aligned}
$$

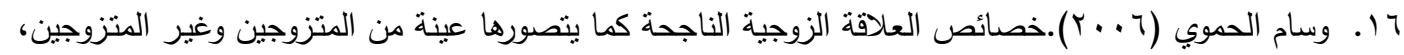

$$
\begin{aligned}
& \text { دراسة ميدانية في مدينة دمشق، مجلة جامعة دمشق، العدد الأول، المجلد (r (Y)، سوريا. } \\
& \text { ثانيا : المراجع الأجنبية }
\end{aligned}
$$

1- Alexandra Hambrights(2001). A Qualitative study of sex difference in the relation narratives of recently married women and man, Dissertations and theses.

2- Bacha(1999). live is mere enough, haw couples can overcome misunderstandings, and solve relationship problems through cognitive therapy ( NY : Row publishers ).

3- Barry C (2006) Adjustment, Retrieved an (20/12/2006) available at www.yahoo.com./adj/htm.

4- Carin Levin (1996) . An exploitation of continuity in attachment patterns, Johhsupiv ,NY.

5- Froma . wolsh (1982). Normal family processes, NY, the cupboard press.

6- Harrey, Jomming (2007) . The long term effects \& the couple communication program, journal , issue 4, volume 8, Jun.

7- Morna Orugh S.D(1993). Desired family size and desired child education among recently married women in Egypt, the John;s Hopkins university.

8- Robert Barker (2003). The social work dictionary , $4^{\text {th }}$. , Washington D.G.N.A.S Press.

9- Walter Schumn \& et.al. (2000). Perceived premarital counseling outcomes among recently married army personnel, Journal of sex \& married therapy , Vo1. 26(2). 